\title{
Ventilator-associated pneumonia after cardiac surgery: A meta-analysis and systematic review
}

\author{
Siyi He, MD, ${ }^{\mathrm{a}, \mathrm{b}}$ Bocheng Chen, MD, ${ }^{\mathrm{a}}$ Wei Li, MD, ${ }^{\mathrm{a}}$ Junyan Yan, MD, ${ }^{\mathrm{a}}$ Lin Chen, MD, \\ Xuefeng Wang, MD, ${ }^{a}$ and Yingbin Xiao, $\mathrm{MD}^{\mathrm{a}}$
}

Objective: Ventilator-associated pneumonia (VAP) is the most common and serious nosocomial infection that
threatens patients who have undergone cardiac surgery. This article summarizes its clinical characteristics and
provides theoretical evidence for prevention and treatment.

Methods: A literature search was conducted using PubMed, Embase, the Cochrane Library, and Web of Knowledge databases and by manual search. Data involving the prevalence, etiology, risk factors, or clinical outcomes were extracted for systematic review and meta-analysis.

\begin{abstract}
Results: Eleven studies on VAP after cardiac surgery were included. When the results were merged the VAP rate was $21.27 / 1000$ ventilator-days. The prevalence reached $6.37 \%$ of all patients and $35.2 \%$ of patients who were on mechanical ventilation for more than 48 hours. Among the isolated pathogens, Pseudomonas aeruginosa had the highest detection rate, with an average of $23.19 \%$, followed by Staphylococcus aureus (20.15\%), Haemophilus influenzae (19.53\%), Acinetobacter baumannii (10.68\%), Escherichia coli (10.18\%), Klebsiella pneumoniae $(9.52 \%)$, and Candida albicans $(7.20 \%)$. Risk factors were also analyzed. We found that New York Heart Association cardiac function class IV, pulmonary hypertension, chronic obstructive pulmonary disease, peripheral vascular disease, renal disease, emergency surgery, intra-aortic balloon counterpulsation, cardiopulmonary bypass time, aortic crossclamp time, mechanical ventilation time, reintervention, and reintubation were closely related to the occurrence of VAP; there was no association with gender and diabetes mellitus. Once patients had VAP, mortality and length of stay in the intensive care unit were significantly increased.
\end{abstract}

Conclusions: VAP in patients after cardiac surgery is common and has a poor prognosis. It is mainly caused by gram-negative bacteria, and could be affected by a series of factors. (J Thorac Cardiovasc Surg 2014;148:3148-55)

See related commentary on pages 3155-6.

Supplemental material is available online.

Ventilator-associated pneumonia (VAP), defined as pulmonary infection developing 48 hours or more after initiation of mechanical ventilation, is one of the most common nosocomial infections in critically ill patients. ${ }^{1}$ It is reported that VAP is responsible for a significant increase in mortality and morbidity, and is associated with the highest costs resulting from prolonged hospitalization, pharmacologic treatment, and so forth. ${ }^{2,3}$

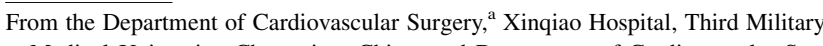
Medical University, Chongqing, China; and Department of Cardiovascular Surgery, ${ }^{\text {b }}$ Chengdu Military General Hospital, Chengdu, China

Disclosures: Authors have nothing to disclose with regard to commercial support.

Received for publication Feb 13, 2014; revisions received June 14, 2014; accepted for publication July 28, 2014; available ahead of print Sept 18, 2014.

Address for reprints: Yingbin Xiao, MD, Department of Cardiovascular Surgery, Xinqiao Hospital, Third Military Medical University, Xinqiao St, Shapingba District, Chongqing, China 400037 (E-mail: xiaoyingbin001@163.com). 0022-5223/\$36.00

Copyright (c) 2014 by The American Association for Thoracic Surgery http://dx.doi.org/10.1016/j.jtcvs.2014.07.107
Once patients need intubation or ventilator support, the risk of VAP is increased 7- to 21 -fold. ${ }^{4}$ Patients who have undergone cardiac surgery and a stay in the intensive care unit (ICU) usually need long-time mechanical ventilation; they represent a special subpopulation at high risk for VAP. ${ }^{5}$ However, limited information exists regarding the clinical characteristics of VAP in this setting, and most studies were carried out in a single institution. The incidence of VAP reported in these studies varies widely. Several studies describe the pathogenic microorganisms, but the conclusions remain controversial. In addition, there is no consensus on what contributes to the occurrence of postoperative VAP. Therefore, a detailed, systematic, and comprehensive summary is urgently needed.

In the present study, we selected eligible studies related to VAP in all populations undergoing cardiac surgery, and then performed a systematic review and meta-analysis of its prevalence, etiology, risk factors, and clinical outcomes. Our objective was to provide clinical evidence for the prevention and treatment of VAP after cardiac surgery.

\section{METHODS \\ Search Strategy}

A literature search was conducted using PubMed, the Excerpta Medica database (Embase), and the Cochrane Library and Web of Knowledge databases up to October 2013. No language or country restrictions were 


$$
\begin{aligned}
& \text { Abbreviations and Acronyms } \\
& \begin{aligned}
\text { CI } & =\text { confidence interval } \\
\text { COPD } & =\text { chronic obstructive pulmonary disease } \\
\text { CPB } & =\text { cardiopulmonary bypass } \\
\text { IABC } & =\text { intra-aortic balloon counterpulsation } \\
\text { ICU } & =\text { intensive care unit } \\
\text { MV } & =\text { mechanical ventilation } \\
\text { NOS } & =\text { Newcastle-Ottowa Scale } \\
\text { NYHA } & =\text { New York Heart Association } \\
\text { OR } & =\text { odds ratio } \\
\text { VAP } & =\text { ventilator-associated pneumonia }
\end{aligned}
\end{aligned}
$$

applied. We used exploded Medical Subject Headings and appropriate corresponding terms as follows: ("ventilator associated pneumonia" OR "nosocomial pneumonia") AND ("cardiac" OR "heart" OR "cardiopulmonary bypass" OR "extracorporeal circulation"). Reference lists of published studies were also manually searched for further relevant studies. Our search strategy was in accordance with the PRISMA (Preferred Reporting Items for Systematic Reviews and Meta-Analysis) guidelines. ${ }^{6}$

\section{Inclusion Criteria and Study Selection}

Studies included in the present analysis met the following inclusion criteria: (1) a clear definition and diagnosis of VAP was included; (2) all enrolled patients had undergone heart operations; (3) articles must provide 1 or more index for the prevalence, etiology, risk factors, or clinical outcomes of VAP; (4) a corresponding comparison group was used; (5) when multiple publications seemed to contain duplicate results, the study with the largest population was included. An article was excluded if it did not fulfill all of these criteria. Reviews and repeated literature were also excluded. Potential eligible articles were screened by 2 reviewers (S.H. and Y.X.) independently and in duplicate according to the inclusion and exclusion criteria. Reviewers resolved disagreements by consensus or, when a discrepancy remained, through discussion with a third reviewer.

\section{Data Extraction}

Two raters independently extracted all valuable data from the final set of eligible articles, which included basic information, prevalence, causes, risk factors (age, gender, New York Heart Association (NYHA) cardiac function class IV, pulmonary hypertension, diabetes mellitus, chronic obstructive pulmonary disease (COPD), peripheral vascular disease, emergency surgery, intra-aortic balloon counterpulsation (IABC), cardiopulmonary bypass (CPB) time, renal disease, aortic crossclamp time, mechanical ventilation time, reintervention, reintubation), and indexes representing clinical outcomes (mortality and length of stay in the ICU), to provide a comprehensive description of VAP after cardiac surgery.

\section{Quality Assessment}

The quality of the studies used in this analysis was evaluated using the Newcastle-Ottawa Scale (NOS). ${ }^{7}$ The studies were judged based on 3 broad perspectives: selection (4 items), comparability (1 item), and exposure or outcome ( 3 items) by a star rating system with a score ranging from 0 to 9. A high-quality study should achieve 7 stars or more, a medium quality study between 4 and 6 stars, and a poor-quality study less than 4 stars.

\section{Statistical Analysis}

Pooled patient information as well as the incidence and causes of VAP after cardiac surgery were characterized using descriptive statistics; an overall meta-analysis was performed to summarize the risk factors and clinical outcomes. The results were synthesized and analyzed using the
Review Manager Software (RevMan 5.2; Cochrane Collaboration. Oxford, United Kingdom). For measurement data, the weighted mean difference and $95 \%$ confidence intervals (CIs) were calculated to compare the mean difference. For count data, odds ratios (ORs) and 95\% CIs were used. Statistical heterogeneity was assessed using the $\mathrm{I}^{2}$ statistic. When $\mathrm{I}^{2}$ was greater than $50 \%$, heterogeneity was considered to be present and we selected the random effect models for the analysis. Otherwise, a fixed effect model was used. The possibility of publication bias, which can result from small unpublished studies with negative results, was assessed visually using a funnel plot for asymmetry.

\section{RESULTS}

\section{Search Results and Study Selection}

A total of 814 articles were initially identified in the PubMed, Embase, Cochrane Library, and Web of Knowledge databases or by a manual approach using the key words as described earlier. After duplicates were removed, 462 potentially relevant articles remained. Based on titles and abstracts, a further 387 articles were subsequently excluded. Of the 75 remaining articles, there was no appropriate comparison group in 34 articles. Twelve articles were removed because there was no specific definition for VAP. Patients enrolled in 8 studies did not all undergo cardiac surgery. We could not extract a useful index for description of VAP in 5 articles. In addition, there were 3 review articles, and the full-length article could not be retrieved for 2 studies. Finally, 11 articles were included in this systematic review (Figure 1). ${ }^{8-18}$ The meta-analysis was based on 9 articles, excluding 1 descriptive study ${ }^{11}$ and 1 questionnaire survey. ${ }^{15}$

\section{Study Characteristics and Quality Assessment}

A total of 11 studies including 10,708 patients were enrolled in our study. Basic information is summarized in Table 1. Nine articles were included in the meta-analysis; 3 articles were case-control studies and 6 articles were cohort studies. After evaluated by NOS, 2 articles got 5 stars, 4 articles got 6 stars, and 3 articles got 7 stars (Table E1). No poor-quality articles were included in our study.

\section{Prevalence}

The prevalence of VAP among patients who had undergone cardiac surgery was described in 9 articles, and the mean value was $6.37 \%$. The lowest level reported previously was $2.1 \%$ and the highest was $13 \%$. In patients who had mechanical ventilation for more than 48 hours, the averaged incidence of VAP was $35.2 \%$ (range, $17.9 \%-53 \%$ ). A conclusion from 6 articles also found that an average of 21.27 VAP episodes occurred per 1000 days of mechanical ventilation (range, 13.9-34.5). These data (Table 2) indicate that the prevalence of VAP after cardiac surgery is high, especially among those under mechanical ventilation for more than 48 hours.

\section{Etiology}

Nine papers reported the microorganisms responsible for VAP (Table 3). Among the gram-positive bacteria, 


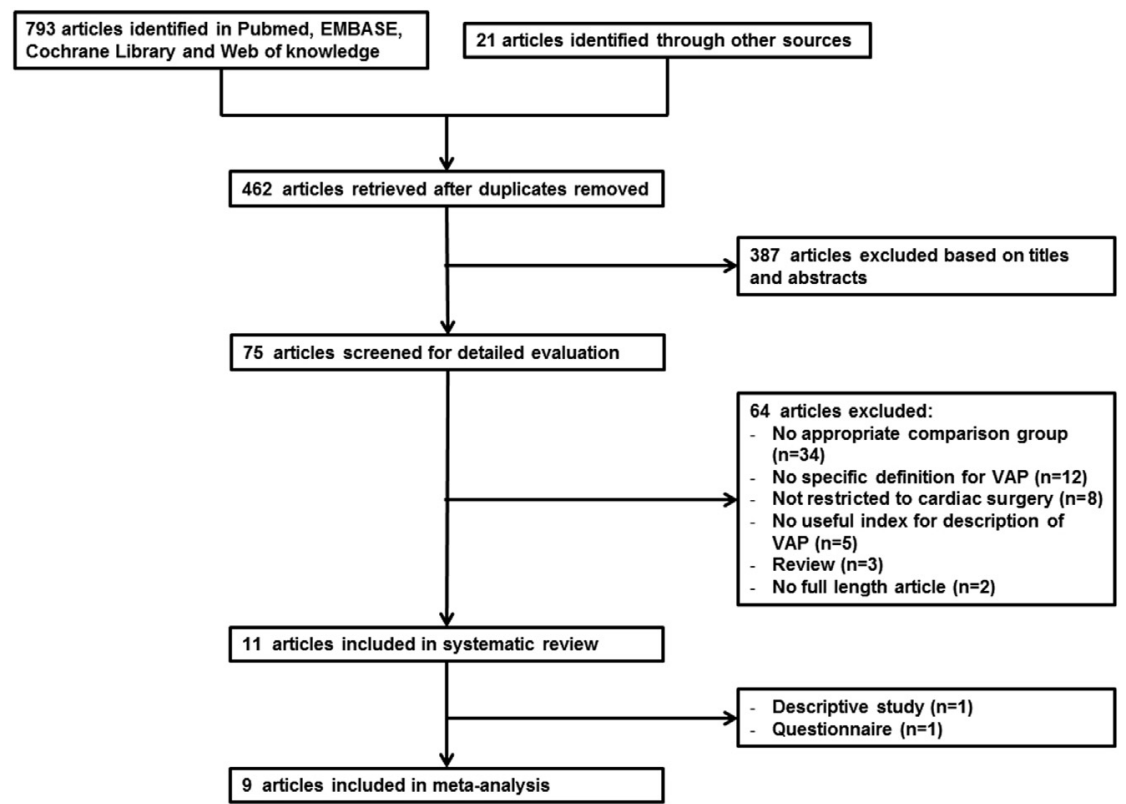

FIGURE 1. Flow diagram of the study selection process. VAP, Ventilator-associated pneumonia.

Staphylococcus aureus was detected most frequently, accounting for $20.15 \%$ of total pathogens with a standard deviation of $12.89 \%$. The mean values for methicillinsensitive Staphylococcus aureus and methicillin-resistant Staphylococcus aureus were $13.13 \%$ and $14.13 \%$, respectively. Among the gram-negative bacteria, Pseudomonas aeruginosa was the most important with a mean detection rate of $23.19 \%$. Some other gram-negative bacteria also played a significant role in the occurrence of VAP, including Klebsiella $(9.52 \% \pm 4.77 \%)$, Acinetobacter $(10.68 \% \pm 9.22 \%)$, Escherichia coli $(10.18 \% \pm 7.53 \%)$, Stenotrophomonas maltophilia $(4.78 \% \pm 3.47 \%)$, Haemophilus influenza $(19.53 \% \pm 18.22 \%)$, Proteus vulgaris $(2.37 \% \pm 2.29 \%)$, and Shewanella oneidensis

TABLE 1. Basic characteristics of the studies

\begin{tabular}{|c|c|c|c|c|c|c|}
\hline \multirow[b]{2}{*}{ Study } & \multicolumn{2}{|c|}{ Number of patients } & \multicolumn{2}{|c|}{ Age (years)* } & \multicolumn{2}{|c|}{ Gender (male/female) } \\
\hline & VAP & Non-VAP & VAP & Non-VAP & VAP & Non-VAP \\
\hline Sheng, $2012^{8}$ & 105 & 1583 & \multicolumn{2}{|c|}{$54.0 \pm 13.5$} & $78 / 27$ & $869 / 714$ \\
\hline Tamayo, $2012^{9}$ & 124 & 1486 & $68.5 \pm 10.0$ & $67.8 \pm 10.5$ & $46 / 78$ & $584 / 902$ \\
\hline Roeleveld, 2011 ${ }^{10}$ & 11 & 114 & $2.4 \pm 4.2$ & $1.3 \pm 2.2$ & $7 / 4$ & $61 / 53$ \\
\hline Wojkowska-Mach, $2009^{11}$ & 53 & 2367 & - & - & - & - \\
\hline Tang, $2009^{12}$ & 13 & 87 & $0.68 \pm 0.96$ & $4.14 \pm 5.84$ & $7 / 6$ & $45 / 42$ \\
\hline Hortal, $2009^{13}$ & 106 & 1738 & \multicolumn{2}{|c|}{$64.7 \pm 12.5$} & \multicolumn{2}{|c|}{$1058 / 786$} \\
\hline Hortal, $2009^{14}$ & 20 & 951 & \multicolumn{2}{|c|}{$64.1 \pm 12.2$} & \multicolumn{2}{|c|}{$690 / 281$} \\
\hline Boaza, $2006^{15}$ & 24 & 296 & - & - & - & - \\
\hline Pawar, $2003^{16}$ & 25 & 927 & $59.7 \pm 12.7$ & $56.5 \pm 10.7$ & $21 / 4$ & $818 / 109$ \\
\hline Bouza, $2003^{17}$ & 52 & 304 & $64.09 \pm 11.2$ & & \multicolumn{2}{|c|}{$223 / 113$} \\
\hline Torres, $1990^{18}$ & 78 & 244 & $54.5 \pm 17.7$ & & $55 / 23$ & $162 / 82$ \\
\hline
\end{tabular}


$(3.8 \% \pm 4.34 \%)$. Some fungi, such as Candida albicans, were detected $(7.2 \% \pm 6.58 \%)$. Several other VAP pathogens were found. Two additional patients were found to be infected with Rhinovirus. ${ }^{10}$ Polymicrobial infections and even negative cultures were also reported in previous literature. From the data, it was concluded that VAP after cardiac surgery is a multifactorial disease, mainly caused by gram-negative bacteria. Staphylococcus aureus and Pseudomonas aeruginosa were found to be the 2 major contributors, at almost half of all pathogens.

\section{Risk Factors}

Fifteen potential risk factors (reported in at least 3 studies) are summarized in the present meta-analysis, divided into 3 categories: preoperative (age, gender, NYHA cardiac function class IV, pulmonary hypertension, diabetes mellitus, COPD, peripheral vascular disease, renal disease), intraoperative (emergency surgery, IABC, CPB time, aortic crossclamp time), and postoperative (mechanical ventilation time, reintervention, reintubation).

Age. Six studies including 6319 patients indicated there was no association between age and the occurrence of VAP after cardiac surgery in children (random effect model; $P=.57 ; 95 \%$ confidence interval $[\mathrm{CI}],-69.33,38.14)$, adults (fixed effect model; $P=.26 ; 95 \% \mathrm{CI},-0.73$, 2.73). However, VAP was more likely to occur in elderly people more than 70 years of age (fixed effect model; $P<.01 ; 95 \%$ CI, 2.17, 3.94) (Figure 2, A).
Gender (male). Six studies including 4797 patients indicated there was no association between gender and the occurrence of VAP after cardiac surgery (random effect model; $P=.29 ; 95 \%$ CI, 0.82, 1.93) (Figure 2, $B$ ).

NYHA cardiac function class IV. Three studies including 3888 patients indicated that VAP was more likely to occur in patients with NYHA cardiac function class IV after cardiac surgery (random effect model; $P<.01 ; 95 \% \mathrm{CI}$, 1.68, 5.73) (Figure 2, C).

Pulmonary hypertension. Three studies including 3657 patients indicated that VAP was more likely to occur in patients with pulmonary hypertension (fixed effect model; $P=.01 ; 95 \%$ CI, 1.13, 2.38) (Figure 2, D).

Diabetes mellitus. Four studies including 6094 patients indicated that there was no association between diabetes mellitus and the occurrence of VAP after cardiac surgery (fixed effect model; $P=.10 ; 95 \%$ CI, 0.97, 1.53) (Figure 2, E).

Chronic obstructive pulmonary disease. Five studies including 6416 patients indicated that VAP was more likely to occur in patients with COPD (fixed effect model; $P<.01$; $95 \%$ CI, 1.18, 2.01) (Figure 2, F).

Peripheral vascular disease. Three studies including 4425 patients indicated that VAP was more likely to occur in patients with peripheral vascular disease (random effect model; $P=.01 ; 95 \%$ CI, 1.40, 19.59) (Figure 2, $G$ ).

Renal disease. Four studies including 6113 patients indicated that VAP was more likely to occur in patients with

TABLE 1. Continued

\begin{tabular}{|c|c|c|c|c|c|c|c|}
\hline \multicolumn{2}{|c|}{ Duration of MV (days) } & \multicolumn{2}{|c|}{ Mortality } & \multicolumn{2}{|c|}{ Types of operation } & \multirow[b]{2}{*}{ Study type } & \multirow[b]{2}{*}{ Definition of VAP } \\
\hline VAP & Non-VAP & VAP & Non-VAP & VAP & Non-VAP & & \\
\hline $9.6(6.1-12) \dagger$ & $0.7(0.6-0.8) \dagger$ & 27 & 46 & 421 valve, $625 \mathrm{CABG}, 48$ valve $+\mathrm{CABC}$ & 116 aorta, 478 others & Case-control study & $\begin{array}{l}\text { American Thoracic } \\
\text { Society }\end{array}$ \\
\hline \multirow[t]{2}{*}{$25.2 \pm 26.2^{*}$} & $1.8 \pm 7.2^{*}$ & 61 & 30 & 72 valve, 34 CABG, 15 valve + CABG & $\begin{array}{l}945 \text { valve, } 631 \mathrm{CABG} \\
15 \text { valve }+ \text { CABG }\end{array}$ & Cohort study & $\mathrm{CDC}$ \\
\hline & & & & 1017 valve, $665 \mathrm{CABG}, 30$ valve $+\mathrm{CAB}$ & & & \\
\hline $7.6 \pm 3.9^{*}$ & $4.9 \pm 5.8^{*}$ & 0 & 3 & - & - & Case-control study & $\mathrm{CDC}$ \\
\hline - & - & - & - & - & - & Descriptive study & $\mathrm{CDC}$ \\
\hline \multirow[t]{2}{*}{$26.92 \pm 8.55^{*}$} & $2.95 \pm 0.41 *$ & 5 & 4 & $\begin{array}{l}12 \text { complex CHD correction surgery, } 1 \\
\text { simple CHD correction surgery }\end{array}$ & $\begin{array}{l}34 \text { complex CHD correction surgery, } \\
53 \text { simple CHD correction surgery }\end{array}$ & Case-control study & NNISS \\
\hline & & & & 46 complex CHD correction surgery, 54 & mple CHD correction surgery & & \\
\hline $9(5.7-24) \dagger$ & $1(1-1) \dagger$ & 48 & 49 & $\begin{array}{l}971 \text { valve, } 393 \text { CABG, } 176 \text { valve }+ \text { CAB } \\
114 \text { others }\end{array}$ & , 61 heart transplantation, 129 aorta, & Cohort study & $\mathrm{CDC}$ \\
\hline $9.5(5-29) \dagger$ & $1(1-1) \dagger$ & 7 & 22 & $\begin{array}{l}267 \text { valve, } 528 \text { CABG, } 76 \text { valve }+ \text { CABC } \\
40 \text { others }\end{array}$ & 14 heart transplantation, 46 aorta, & Cohort study & $\mathrm{CDC}$ \\
\hline - & - & - & - & - & - & $\begin{array}{l}\text { Questionnaire } \\
\text { survey }\end{array}$ & $\mathrm{CDC}$ \\
\hline $6.4 \pm 4.8^{*}$ & $0.8 \pm 0.3 *$ & 4 & 2 & - & - & Cohort study & Own description \\
\hline $3.5 \pm 3.6^{*}$ & $0.7 \pm 1.2 *$ & - & - & $\begin{array}{l}178 \text { valve, } 128 \text { CABG, } 22 \text { valve }+\mathrm{CABC} \\
\text { correction surgery, } 2 \text { pericardiectomy, }\end{array}$ & $\begin{array}{l}11 \text { heart transplantation, } 7 \mathrm{CHD} \\
\text { aorta }\end{array}$ & Cohort study & $\mathrm{CDC}$ \\
\hline - & - & 26 & 47 & - & - & Cohort study & Own description \\
\hline
\end{tabular}


TABLE 2. Prevalence of ventilator-associated pneumonia after cardiac surgery

\begin{tabular}{|c|c|c|c|}
\hline Study & $\begin{array}{c}\text { VAP in all } \\
\text { patients }(\%)\end{array}$ & $\begin{array}{c}\text { VAP in patients } \\
\text { requiring MV } \\
\text { for }>\mathbf{4 8} \text { hours }(\%)\end{array}$ & $\begin{array}{c}\text { VAP episodes } \\
\text { per } 1000 \text { days } \\
\text { of MV } \\
\end{array}$ \\
\hline Sheng, $2012^{8}$ & 6.2 & 53 & - \\
\hline Tamayo, $2012^{9}$ & 7.7 & - & - \\
\hline Roeleveld, $2011^{10}$ & 8.8 & - & 17.1 \\
\hline $\begin{array}{l}\text { Wojkowska-Mach, } \\
2009^{11}\end{array}$ & 2.2 & - & 18.3 \\
\hline Tang, $2009^{12}$ & 13 & - & 21.6 \\
\hline Hortal, $2009^{13}$ & 5.7 & 45.9 & 22.2 \\
\hline Hortal, $2009^{14}$ & 2.1 & 17.9 & 13.9 \\
\hline Boaza, $2006^{15}$ & 7.5 & - & - \\
\hline Bouza, $2003^{17}$ & 7.87 & - & 34.5 \\
\hline Torres, $1990^{18}$ & - & 24 & - \\
\hline Average & 6.37 & 35.2 & 21.27 \\
\hline
\end{tabular}

$V A P$, Ventilator-associated pneumonia; $M V$, mechanical ventilation.

renal disease (random effect model; $P<.01 ; 95 \%$ CI, 1.76 , 5.84) (Figure 2, $H$ ).

Emergency surgery. Three studies including 4484 patients indicated that VAP was more likely to occur in patients who underwent emergency surgery (random effect model; $P<.01 ; 95 \%$ CI, 1.99, 10.90) (Figure E1, $A$ ).

Intra-aortic balloon counterpulsation. Four studies including 5455 patients indicated that VAP was more likely to occur in patients with IABC implantation (random effect model; $P<.01 ; 95 \%$ CI, 3.28, 10.01) (Figure E1, $B$ ).

Cardiopulmonary bypass time. Five studies including 5367 patients indicated that prolonged CPB time may increase the risk for VAP after cardiac surgery (fixed effect model; $P<.01 ; 95 \%$ CI, 19.75, 29.09) (Figure E1, $C$ ).

Aortic crossclamp time. Five studies including 5367 patients indicated that prolonged aortic crossclamp time may increase the risk for VAP after cardiac surgery (fixed effect model; $P<.01 ; 95 \%$ CI, 8.84, 19.20) (Figure E1, D). Mechanical ventilation time. Five studies including 3143 patients indicated that prolonged mechanical ventilation time may increase the risk for VAP after cardiac surgery (random effect model; $P<.01 ; 95 \% \mathrm{CI}, 70.98,218.21$ ) (Figure E2, A).

Reintervention. Six studies including 7190 patients indicated that postoperative reintervention was an important factor causing VAP (random effect model; $P<.01$; 95\% CI, 1.80, 6.31) (Figure E2, B).

Reintubation. Four studies including 4210 patients indicated that postoperative reintubation was an important factor causing VAP (random effect model; $P<.01 ; 95 \%$ CI, 5.15, 68.77) (Figure E2, C).

These results demonstrated that NYHA cardiac function class IV, pulmonary hypertension, COPD, peripheral vascular disease, renal disease, emergency surgery, IABC, CPB time, aortic crossclamp time, mechanical ventilation time, reintervention and reintubation were risk factors for
VAP after cardiac surgery, whereas gender and diabetes mellitus were not.

\section{Clinical Outcomes}

Eight studies including 7612 patients indicated that mortality was increased significantly in patients infected with VAP (random effect model; $P<.01 ; 95 \%$ CI, 5.81, 39.68) (Figure E3, A). Length of stay in the ICU was also affected by VAP according to data extracted from 5 studies involving 4475 patients (random effect model; $P<.01 ; 95 \% \mathrm{CI}, 6.65$, 39.91) (Figure E3, $B$ ). These results suggest that VAP after cardiac surgery is closely related to a poor prognosis.

\section{Publication Bias}

To determine publication bias in the present study, we drew funnel plots as the evaluation criteria. The results showed that symmetry was good in the analysis of pulmonary hypertension, diabetes mellitus, COPD, CPB time and aortic crossclamp time; some publication bias existed in other analyses (Figure E4).

\section{DISCUSSION}

VAP is the most frequently encountered nosocomial infection in all ICUs. Great challenges still remain in the diagnosis of VAP, because of its various clinical manifestations and pathogens. ${ }^{19}$ The clinical criteria for VAP are commonly based on the guidelines from the Centers for Disease Control and Prevention. It is defined as the presence of new and/or progressive pulmonary infiltrates on a chest radiograph, plus 2 or more of the following: fever $\left(\geq 38.5^{\circ} \mathrm{C}\right)$ or hypothermia $\left(<36^{\circ} \mathrm{C}\right)$, leukocytosis $\left(\geq 12 \times 10^{9} / \mathrm{L}\right)$, purulent tracheobronchial secretions, or a reduction in $\mathrm{PaO}_{2} / \mathrm{Fio}_{2}$ (partial pressure of arterial oxygen/ fraction of inspired oxygen) of $15 \%$ or more in the previous 48 hours, ${ }^{20}$ Bacteriologic cultures, serum biomarkers, and some other techniques are also useful for diagnosing VAP, however, their contributions are considered limited. ${ }^{21}$

Heart surgery, especially $\mathrm{CPB}$, often triggers an abnormal systemic inflammatory reaction and releases a series of proinflammatory mediators. ${ }^{22,23}$ Combined with other factors, such as anesthesia and hypothermia, impaired lung function is common in this subpopulation, leading to the need for long-term mechanical ventilation. ${ }^{24}$ Previous studies have suggested that prolonged weaning may disrupt the normal barrier in the respiratory tract, thus increasing the risk for infections and leading to high mortality. ${ }^{25}$ As a result, a high prevalence of VAP can be expected in patients who have undergone cardiac surgery, which is verified in our study.

A good prognosis is usually attributable to the initial treatment of VAP with an appropriate antimicrobial regimen. ${ }^{26}$ Some previous studies found that early administration of antibiotics could prevent undue prolongation of mechanical ventilation and reduce mortality in patients 
TABLE 3. Detection rate of pathogens in patients infected with ventilator-associated pneumonia after cardiac surgery ( $\%)$

\begin{tabular}{|c|c|c|c|c|c|c|c|c|c|c|}
\hline Pathogen & $\begin{array}{l}\text { Sheng, } \\
{2012^{8}}^{8}\end{array}$ & $\begin{array}{c}\text { Tamayo, } \\
\mathbf{2 0 1 2}^{9}\end{array}$ & $\begin{array}{c}\text { Roeleveld, } \\
\text { 2011 }^{10}\end{array}$ & $\begin{array}{c}\text { Wojkowska-Mach, } \\
2^{2009^{11}}\end{array}$ & $\begin{array}{l}\text { Tang, } \\
2009^{12}\end{array}$ & $\begin{array}{l}\text { Hortal, } \\
2009^{13}\end{array}$ & $\begin{array}{l}\text { Pawar, } \\
2003^{16}\end{array}$ & $\begin{array}{l}\text { Bouza, } \\
\mathbf{2 0 0 3}^{17}\end{array}$ & $\begin{array}{l}\text { Torres, } \\
1^{1990^{18}}\end{array}$ & Mean \pm SD \\
\hline \multicolumn{11}{|l|}{ Gram-positive } \\
\hline Staphylococcus aureus & 15.7 & 44.3 & 18.2 & 4.2 & 25 & 27.1 & 9.5 & 17.2 & 2.6 & $20.15 \pm 12.89$ \\
\hline MSSA & - & 20.1 & - & - & 10 & 9.3 & - & - & - & $13.13 \pm 6.04$ \\
\hline MRSA & - & 9.6 & - & - & 15 & 17.8 & - & - & - & $14.13 \pm 4.17$ \\
\hline \multicolumn{11}{|l|}{ Gram-negative } \\
\hline Pseudomonas aeruginosa & 24.2 & 20.9 & 9.1 & 10.4 & 45 & 28.6 & 52.3 & 17.2 & 6.4 & $23.19 \pm 15.95$ \\
\hline Klebsiella & 13.6 & 7.3 & - & 16.7 & 5 & 5 & 9.5 & - & - & $9.52 \pm 4.77$ \\
\hline Acinetobacter & 10.6 & 28.2 & - & 6.3 & - & 2.8 & 4.7 & - & 11.5 & $10.68 \pm 9.22$ \\
\hline Escherichia coli & 8.1 & 2.4 & - & 12.5 & 5 & 9.3 & 23.8 & - & - & $10.18 \pm 7.53$ \\
\hline $\begin{array}{l}\text { Stenotrophomonas } \\
\text { maltophilia }\end{array}$ & 6.1 & 0.8 & - & - & 10 & 3.6 & - & 3.4 & - & $4.78 \pm 3.47$ \\
\hline Haemophilus influenzae & - & 12.1 & 45.5 & - & - & 17.1 & - & 3.4 & - & $19.53 \pm 18.22$ \\
\hline Proteus vulgaris & - & 0.8 & - & - & - & 5 & - & - & 1.3 & $2.37 \pm 2.29$ \\
\hline Shewanella oneidensis & - & 1.6 & - & - & - & 2 & - & 10.3 & 1.3 & $3.8 \pm 4.34$ \\
\hline \multicolumn{11}{|l|}{ Fungus } \\
\hline Candida albicans & 2 & - & - & 14.6 & 5 & - & - & - & - & $7.2 \pm 6.58$ \\
\hline
\end{tabular}

SD, Standard deviation; MSSA, methicillin-sensitive Staphylococcus aureus; MRSA, methicillin-resistant Staphylococcus aureus.

with VAP, so empirical therapy is essential within 24 hours. $^{27,28}$ For patients who have undergone cardiac surgery, our study revealed that gram-negative bacteria, particularly Pseudomonas aeruginosa, are the major cause of VAP, so we recommend third- or fourthgeneration cephalosporins as the preferred antimicrobial program (eg, cefoperazone, ceftazidime, or cefepime). Other antibiotics against this type of pathogen can also be
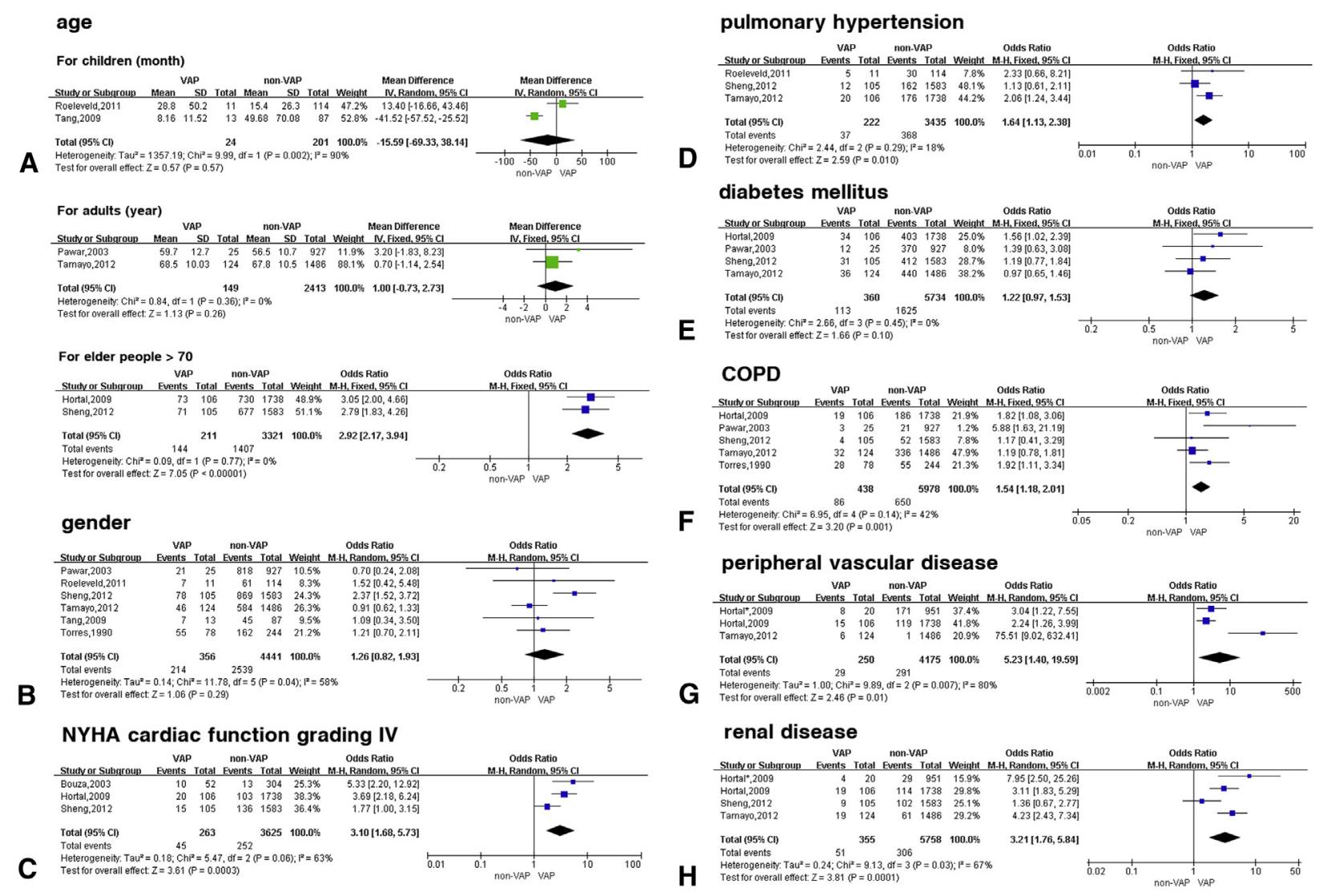

FIGURE 2. Meta-analysis of preoperative risk factors. A, Age; B, gender; C, NYHA cardiac function class IV; D, pulmonary hypertension; E, diabetes mellitus; F, chronic obstructive pulmonary disease; G, peripheral vascular disease; H, renal disease. VAP, Ventilator-associated pneumonia; $S D$, standard deviation; $I V$, inverse variance; $C I$, confidence interval; $M-H$, Mantel-Haenszel; $C O P D$, chronic obstructive pulmonary disease. 
chosen. Combination therapy was once believed to be associated with better microbiological and clinical outcomes, ${ }^{29}$ despite high cost, greater toxicity, and potential drug resistance. ${ }^{30}$ However, this was recently refuted by a meta-analysis of randomized trials, which proved that there was no significant difference between monotherapy and combination therapy with regard to efficacy and mortality, and a superior empirical regimen was still not evident. ${ }^{31}$ The microbial pathogens are not the same in different settings or different regions, thus experience from the local institution seems especially important. Once the results of bacteriologic cultures are available, the antibiotics should be adjusted to sensitive drugs as quickly as possible.

In addition to empirical therapy, preventive measures aiming at the risk factors are also significant. Our study found 6 valuable preoperative risk factors. Before surgery, we advocate aggressive therapies for existing diseases to reduce the risks for VAP; for example, improve cardiac and renal function, alleviate pulmonary hypertension, treat COPD or peripheral vascular diseases. However, not all preoperative diseases can be cured efficiently, and some factors such as age or gender are immutable. So making a quantitative index for patients seems a promising method of prevention. We can grade patients based on this evidence and provide solutions for each aspect. Hortal and colleagues ${ }^{14}$ have already made some attempt to do this. They developed a day 0 score to identify the population at risk for VAP with variables available before surgery; a day 3 score was developed for patients who remained ventilated for more than 48 hours. They were able to identify $93 \%$ of patients who would develop VAP with a specificity of $40 \%$. However, some researchers pointed that this score was developed based on a small numbers of patients and therefore of limited use. ${ }^{32}$ The results of the present study or other studies should be considered when setting criteria, and the practicalities must also be validated by further research. During surgery, minimizing the CPB time and aortic clamping are key to preventing VAP. In addition, there should be more focus on patients undergoing emergency surgery or undergoing IABC implantation. Favorable postoperative care and nursing are believed to reduce mechanical ventilation time and avoid intubation or reinvention, which could reduce the risk for VAP. ${ }^{33}$

There are some limitations of this study. The patients included in our study all underwent heart surgery. It is reported that the clinical characteristics of patients of different ages are not the same. ${ }^{34}$ Geographic location is also a factor that affects the results. Therefore, our study should be further analyzed in different subgroups classified by age, region, or other factors. In addition, the number of eligible articles seems small. Several aspects that were reported and believed to be responsible for VAP in the literature were not described in our study, just because the results could not be merged from a sufficient number of studies. This is also the reason why publication bias is still present in some analysis. Nursing is also important for the prevention and treatment of VAP after cardiac surgery, but we failed to investigate its effect; this must be studied in future research.

\section{CONCLUSIONS}

In the present study, we selected all eligible studies on VAP after cardiac surgery, demonstrating that patients who have undergone heart operation are commonly infected with VAP. Gram-negative bacteria account for a large proportion of the pathogens, among which Pseudomonas aeruginosa is a major contributor. We also found that VAP is closely related to high mortality and long ICU stay. NYHA cardiac function class IV, pulmonary hypertension, COPD, peripheral vascular disease, renal disease, emergency surgery, IABC, CPB time, aortic crossclamp time, mechanical ventilation time, reintervention, and reintubation are proven risk factors for infection, providing potential targets for the prevention and treatment of VAP after cardiac surgery.

\section{References}

1. Pileggi C, Bianco A, Flotta D, Nobile CG, Pavia M. Prevention of ventilator-associated pneumonia, mortality and all intensive care unit acquired infections by topically applied antimicrobial or antiseptic agents: a meta-analysis of randomized controlled trials in intensive care units. Crit Care. 2011;15:R155.

2. Arabi Y, Al-Shirawi N, Memish Z, Anzueto A. Ventilator-associated pneumonia in adults in developing countries: a systematic review. Int J Infect Dis. 2008;12: 505-12.

3. Rello J, Ollendorf DA, Oster G, Vera-Llonch M, Bellm L, Redman R, et al. Epidemiology and outcomes of ventilator-associated pneumonia in a large US database. Chest. 2002;122:2115-21.

4. Simsek S, Yurtseven N, Gercekogalu H, Izgi F, Sohtorik U, Canik S, et al. Ventilator-associated pneumonias in a cardiothoracic surgery centre postoperative intensive care unit. J Hosp Infect. 2001;47:321-4.

5. Rebollo MH, Bernal JM, Llorca J, Rabasa JM, Revuelta JM. Nosocomial infections in patients having cardiovascular operations: a multivariate analysis of risk factors. J Thorac Cardiovasc Surg. 1996;112:908-13.

6. Moher D, Liberati A, Tetzlaff J, Altman DG. Preferred reporting items for systematic reviews and meta-analyses: the PRISMA statement. PLoS Med. 2009; 6:e1000097.

7. Stang A. Critical evaluation of the Newcastle-Ottawa scale for the assessment of the quality of nonrandomized studies in meta-analyses. Eur J Epidemiol. 2010; 25:603-5.

8. Sheng W, Chi YF, Hou WM, Sun L, Niu ZZ, Sun Y, et al. [Clinical analysis of 105 cases of ventilator-associated pneumonia after heart surgery]. Zhonghua Xin Xue Guan Bing Za zZhi. 2012;40:825-9 (in Chinese).

9. Tamayo E, Alvarez FJ, Martinez-Rafael B, Bustamante J, Bermejo-Martin JF, Fierro I, et al. Ventilator-associated pneumonia is an important risk factor for mortality after major cardiac surgery. J Crit Care. 2012;27:18-25.

10. Roeleveld PP, Guijt D, Kuijper EJ, Hazekamp MG, de Wilde RB, de Jonge E. Ventilator-associated pneumonia in children after cardiac surgery in The Netherlands. Intensive Care Med. 2011;37:1656-63.

11. Wojkowska-Mach J, Baran M, Drwila R, Foryciarz E, Misiewska-Kaczur A, Romaniszyn D, et al. [Ventilator-associated pneumonia after cardiac surgery]. Anestezjologia Intensywna Terapia. 2009;41:224-9 (in Polish).

12. Tang CW, Liu PY, Huang YF, Pan JY, Lee SS, Hsieh KS, et al. Ventilatorassociated pneumonia after pediatric cardiac surgery in southern Taiwan. J Microbiol Immunol Infection. 2009;42:413-9.

13. Hortal J, Munoz P, Cuerpo G, Litvan H, Rosseel PM, Bouza E. Ventilatorassociated pneumonia in patients undergoing major heart surgery: an incidence study in Europe. Crit Care. 2009;13:R80. 
14. Hortal J, Giannella M, Perez MJ, Barrio JM, Desco M, Bouza E, et al. Incidence and risk factors for ventilator-associated pneumonia after major heart surgery. Intensive Care Med. 2009;35:1518-25.

15. Bouza E, Hortal J, Munoz P, Pascau J, Perez MJ, Hiesmayr M. Postoperative infections after major heart surgery and prevention of ventilator-associated pneumonia: a one-day European prevalence study (ESGNI-008). J Hosp Infect. 2006;64:224-30.

16. Pawar M, Mehta Y, Khurana P, Chaudhary A, Kulkarni V, Trehan N. Ventilatorassociated pneumonia: incidence, risk factors, outcome, and microbiology. J Cardiothorac Vasc Anesth. 2003;17:22-8.

17. Bouza E, Perez A, Munoz P, Jesus Perez M, Rincon C, Sanchez C, et al. Ventilator-associated pneumonia after heart surgery: a prospective analysis and the value of surveillance. Crit Care Med. 2003;31:1964-70.

18. Torres A, Aznar R, Gatell JM, Jimenez P, Gonzalez J, Ferrer A, et al. Incidence, risk, and prognosis factors of nosocomial pneumonia in mechanically ventilated patients. Am Rev Respir Dis. 1990;142:523-8.

19. Muscedere J, Dodek P, Keenan S, Fowler R, Cook D, Heyland D. Comprehensive evidence-based clinical practice guidelines for ventilator-associated pneumonia: diagnosis and treatment. J Crit Care. 2008;23:138-47.

20. Garner JS, Jarvis WR, Emori TG, Horan TC, Hughes JM. CDC definitions for nosocomial infections, 1988. Am J Infect Control. 1988;16:128-40.

21. Rea-Neto A, Youssef NC, Tuche F, Brunkhorst F, Ranieri VM, Reinhart K, et al. Diagnosis of ventilator-associated pneumonia: a systematic review of the literature. Crit Care. 2008;12:R56.

22. Warren OJ, Smith AJ, Alexiou C, Rogers PL, Jawad N, Vincent C, et al. The inflammatory response to cardiopulmonary bypass: part 1-mechanisms of pathogenesis. J Cardiothorac Vasc Anesth. 2009;23:223-31.

23. Denizot Y, Nathan N. Interleukin-6 and -10 as master predictive mediators of the postcardiopulmonary bypass inflammatory response (letter). J Thorac Cardiovasc Surg. 2012;144:743; author reply 743-4.
24. Apostolakis E, Filos KS, Koletsis E, Dougenis D. Lung dysfunction following cardiopulmonary bypass. J Card Surg. 2010;25:47-55.

25. Perren A, Brochard L. Managing the apparent and hidden difficulties of weaning from mechanical ventilation. Intensive Care Med. 2013:39:1885-95.

26. Dallas J, Skrupky L, Abebe N, Boyle WA III, Kollef MH. Ventilator-associated tracheobronchitis in a mixed surgical and medical ICU population. Chest. 2011; 139:513-8.

27. Luna CM, Aruj P, Niederman MS, Garzon J, Violi D, Prignoni A, et al. Appropriateness and delay to initiate therapy in ventilator-associated pneumonia. Eur Respir J. 2006;27:158-64.

28. Mariya Joseph N, Sistla S, Kumar Dutta T, Shankar Badhe A, Rasitha D, Chandra Parija S. Outcome of ventilator-associated pneumonia: impact of antibiotic therapy and other factors. Australas Med J. 2012;5:135-40.

29. Heyland DK, Dodek P, Muscedere J, Day A, Cook D. Randomized trial of combination versus monotherapy for the empiric treatment of suspected ventilatorassociated pneumonia. Crit Care Med. 2008;36:737-44.

30. Koontz CS, Chang MC, Meredith JW. Effects of empiric antibiotic administration for suspected pneumonia on subsequent opportunistic pulmonary infections Am Surg. 2000;66:1110-4; discussion 1114-15.

31. Aarts MA, Hancock JN, Heyland D, McLeod RS, Marshall JC. Empiric antibiotic therapy for suspected ventilator-associated pneumonia: a systematic review and meta-analysis of randomized trials. Crit Care Med. 2008;36:108-17.

32. Segers P, de Mol BA. Prevention of ventilator-associated pneumonia after cardiac surgery: prepare and defend! Intensive Care Med. 2009;35:1497-9.

33. Poelaert J, Depuydt P, De Wolf A, Van de Velde S, Herck I, Blot S. Polyurethane cuffed endotracheal tubes to prevent early postoperative pneumonia after cardiac surgery: a pilot study. J Thorac Cardiovasc Surg. 2008;135:771-6.

34. Blot S, Koulenti D, Dimopoulos G, Martin C, Komnos A, Krueger WA, et al. Prevalence, risk factors, and mortality for ventilator-associated pneumonia in middleaged, old, and very old critically ill patients. Crit Care Med. 2014;42:601-9.

\section{EDITORIAL COMMENTARY}

\section{Prevention of ventilator-associated pneumonia in the cardiothoracic intensive care unit: Back to basics}

\author{
Nicholas D. Andersen, MD
}

See related article on pages 3148-55.

Ventilator-associated pneumonia (VAP) is the most common nosocomial infection that occurs after heart surgery and is associated with significant morbidity and mortality. $\mathrm{He}$ and colleagues ${ }^{1}$ performed a contemporary metaanalysis summarizing the prevalence, cause, risk factors,

From the Division of Cardiovascular and Thoracic Surgery, Department of Surgery, Duke University Medical Center, Durham, NC.

Disclosures: Author has nothing to disclose with regard to commercial support.

Received for publication Aug 18, 2014; accepted for publication Aug 20, 2014; available ahead of print Oct 22, 2014.

Address for reprints: Nicholas D. Andersen, MD, Division of Cardiovascular and Thoracic Surgery, Duke University Medical Center, Box 3443, Durham, NC 27710 (E-mail: Nicholas.andersen@duke.edu).

J Thorac Cardiovasc Surg 2014;148:3155-6

0022-5223/\$36.00

Copyright (c) 2014 by The American Association for Thoracic Surgery

http://dx.doi.org/10.1016/j.jtcvs.2014.08.050 and outcome of VAP after cardiac surgery. Results showed that the prevalence of VAP after cardiac surgery was $6.37 \%$, and that the risk of mortality increased 15 -fold in patients with VAP. Several important risk factors associated with VAP were further identified. This study highlights the scope and significance of VAP after cardiac surgery and should redirect attention to basic strategies for VAP prevention.

\section{CLINICAL SUMMARY}

VAP is the most common nosocomial infection that occurs after heart surgery and is associated with significant morbidity and mortality. ${ }^{2} \mathrm{He}$ and colleagues ${ }^{1}$ performed a contemporary meta-analysis and literature review of the prevalence, cause, risk factors, and outcome of VAP after cardiac surgery, described in the current issue of the Journal. The study is of high-quality and sound statistical design, and the data effectively summarize the benchmark rates of VAP, responsible pathogens, risk factors for VAP, and impact of VAP on patient outcomes. 


\section{emergency surgery}

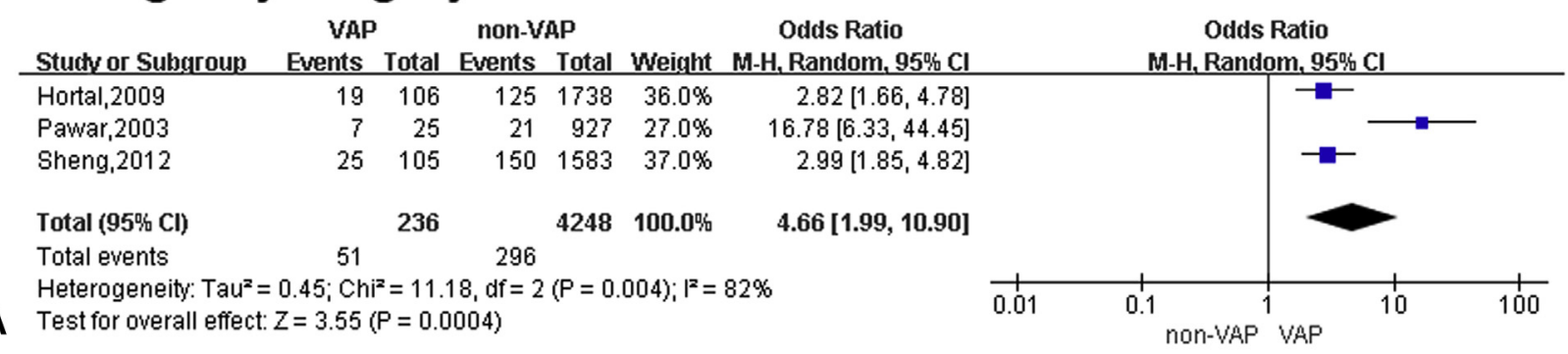

\section{IABC}

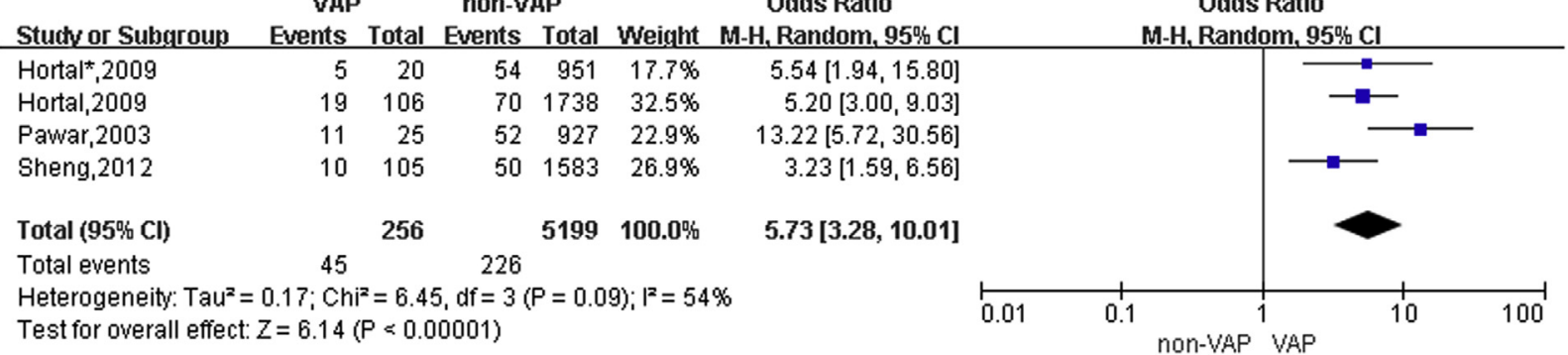

\section{CPB time}

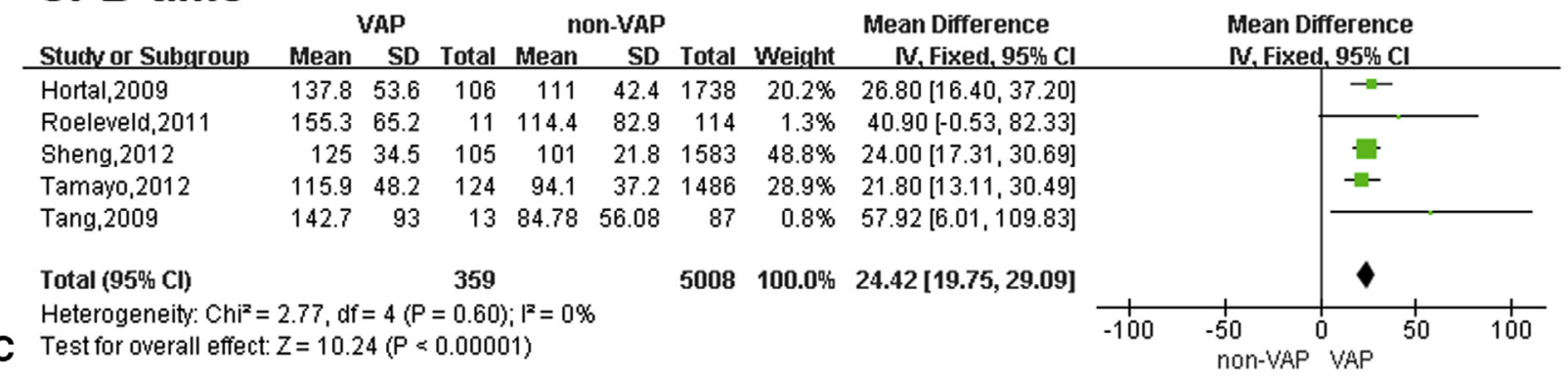

\section{aortic crossclamp time}

\begin{tabular}{|c|c|c|c|c|c|c|c|c|c|c|c|}
\hline \multirow[b]{2}{*}{ Studv or Subqroup } & \multicolumn{3}{|c|}{ VAP } & \multicolumn{3}{|c|}{ nON-VAP } & \multirow{2}{*}{\multicolumn{2}{|c|}{$\begin{array}{lc} & \text { Mean Difference } \\
\text { Weight } \quad \text { N, Fixed, 95\% } \mathrm{Cl}\end{array}$}} & \multirow{2}{*}{\multicolumn{3}{|c|}{$\begin{array}{l}\text { Mean Difference } \\
\text { N, Fixed, 95\% } \mathrm{Cl}\end{array}$}} \\
\hline & Mean & SD & Total & Mean & SD & Total & & & & & \\
\hline Hortal,2009 & 83.3 & 44.7 & 106 & 73.2 & 31.8 & 1738 & $35.9 \%$ & $10.10[1.46,18.74]$ & & & - \\
\hline Roeleveld,2011 & 90.9 & 62.5 & 11 & 57 & 53.8 & 114 & $1.8 \%$ & $33.90[-4.33,72.13]$ & & & \\
\hline Tamayo,2012 & 83.1 & 36.4 & 124 & 67.4 & 28 & 1486 & $62.2 \%$ & $15.70[9.14,22.26]$ & & & - \\
\hline Total $(95 \% \mathrm{Cl})$ & & & 241 & & & 3338 & $100.0 \%$ & $14.02[8.84,19.20]$ & & & \\
\hline $\begin{array}{l}\text { Heterogeneity: } \mathrm{Chi}^{2}= \\
\text { Test for overall effect }\end{array}$ & $\begin{array}{l}2.08, d f \\
Z=5.31\end{array}$ & $\begin{array}{l}=2(P \\
(P=0\end{array}$ & $\begin{array}{l}=0.35) \\
1.00001\end{array}$ & $i^{2}=4$ & & & & & -50 & $\begin{array}{c}1 \\
-25 \\
\text { non-VAP }\end{array}$ & $\underbrace{}_{\text {VAP }} 25$ \\
\hline
\end{tabular}

FIGURE E1. Meta-analysis of intraoperative risk factors. A, Emergency surgery; B, intra-aortic balloon counterpulsation; C, cardiopulmonary bypass time; D, aortic crossclamp time. VAP, Ventilator-associated pneumonia; $M-H$, Mantel-Haenszel; $C I$, confidence interval; $I A B C$, intra-aortic balloon counterpulsation; $C P B$, cardiopulmonary bypass; $S D$, standard deviation; $I V$, inverse variance. 


\section{mechanical ventilation time}

\begin{tabular}{|c|c|c|c|c|c|c|c|c|c|}
\hline \multirow[b]{2}{*}{ Stucty or Subgroup } & \multicolumn{3}{|c|}{ VAP } & \multicolumn{3}{|c|}{ non-VAP } & \multicolumn{2}{|r|}{ Mean Difference } & \multirow{2}{*}{$\begin{array}{c}\text { Mean Difference } \\
\text { N, Random, 95\% Cl }\end{array}$} \\
\hline & Mean & SD & Total & Mean & SD & Total & Weight & N, Random, $95 \% \mathrm{Cl}$ & \\
\hline Bouza,2003 & 85 & 86 & 52 & 17 & 29 & 304 & $22.1 \%$ & $68.00[44.40,91.60]$ & $=$ \\
\hline Pawar,2003 & 153.75 & 114.44 & 25 & 19.65 & 7.99 & 927 & $20.9 \%$ & $134.10[89.24,178.96]$ & $=$ \\
\hline Roeleveld,2011 & 181.3 & 94.4 & 11 & 118.1 & 138.3 & 114 & $19.5 \%$ & $63.20[1.91,124.49]$ & $=$ \\
\hline Tamayo,2012 & 604.8 & 628.8 & 124 & 43.2 & 172.8 & 1486 & $14.9 \%$ & $561.60[450.58,672.62]$ & \\
\hline Tang,2009 & 26.92 & 8.55 & 13 & 2.95 & 0.41 & 87 & $22.6 \%$ & $23.97[19.32,28.62]$ & 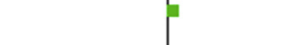 \\
\hline Total $(95 \% \mathrm{Cl})$ & & & 225 & & & 2918 & $100.0 \%$ & $144.59[70.98,218.21]$ & \\
\hline $\begin{array}{l}\text { Heterogeneity: Tau } \\
\text { Test for overall effect }\end{array}$ & $\begin{array}{l}6240.76 \\
Z=3.85\end{array}$ & $\begin{array}{l}\mathrm{Chi}^{2}=1 \\
\mathrm{P}=0.00\end{array}$ & 25.40 & $d f=4(P$ & $\leq 0.00$ & $001) ; I^{2}$ & $=97 \%$ & & $\begin{array}{c}-500-250 \text { o } 250 \\
\text { non-VAP VAP }\end{array}$ \\
\hline
\end{tabular}

\section{re-intervention}

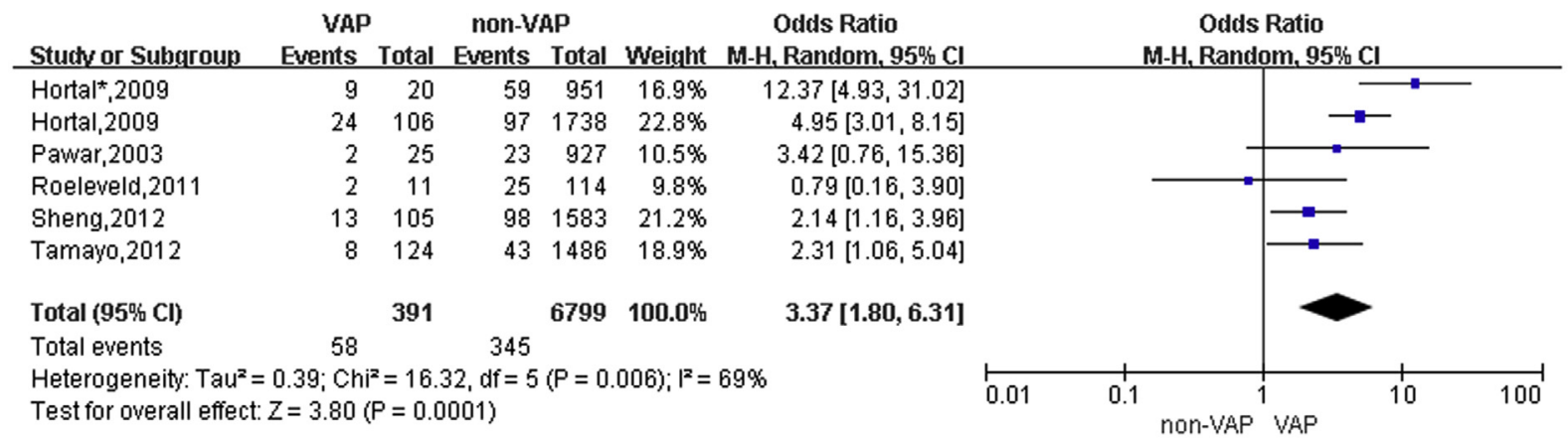

\section{re-intubation}

VAP non-VAP Odds Ratio Odds Ratio

Stuchy or Subqroup Events Total Events Total Weight M-H, Random, 95\% C $\begin{array}{lllllll}\text { Bouza,2003 } & 21 & 52 & 1 & 304 & 17.0 \% & 205.26 \\ {[26.69,1578.32]}\end{array}$ $\begin{array}{llllllr}\text { Hortal,2009 } & 65 & 106 & 67 & 1738 & 28.4 \% & 39.54[24.94,62.69]\end{array}$

$\begin{array}{lllllll}\text { Sheng,2012 } & 12 & 105 & 40 & 1583 & 27.2 \% & 4.98[2.53,9.81]\end{array}$

Torres, 1990

$7.40[3.85,14.23]$

Total (95\% Cl)

Total events 128

$341 \quad 3869 \quad 100.0 \%$

$18.81[5.15,68.77]$

Heterogeneity: Tau $^{2}=1.49 ; \mathrm{Chi}^{2}=37.46, \mathrm{df}=3(\mathrm{P}<0.00001) ; \mathrm{I}^{2}=92 \%$

C Test for overall effect: $Z=4.44(P=0.00001)$

FIGURE E2. Meta-analysis of postoperative risk factors. A, Mechanical ventilation time; B reintervention; C, reintubation. VAP, Ventilator-associated pneumonia; $S D$, standard deviation; $I V$, inverse variance; $C I$, confidence interval; $M-H$, Mantel-Haenszel. 


\section{mortality}

\begin{tabular}{|c|c|c|c|c|c|c|c|c|c|c|}
\hline Stucty or Subqroup & $\begin{array}{l}\text { VAP } \\
\text { Events }\end{array}$ & Total & $\begin{array}{l}\text { non-v } \\
\text { Events }\end{array}$ & AP & Weight & $\begin{array}{c}\text { Odds Ratio } \\
\text { M-H, Random, } 95 \% \mathrm{Cl}\end{array}$ & & $\begin{array}{r}\text { Odds } \\
\text { M.H, Randi }\end{array}$ & $\begin{array}{l}\text { Ratio } \\
\mathrm{om}, 95 \% \mathrm{Cl}\end{array}$ & \\
\hline Hortal $^{*}, 2009$ & 7 & 20 & 22 & 951 & $13.2 \%$ & $22.74[8.27,62.52]$ & & & & -- \\
\hline Hortal,2009 & 48 & 106 & 49 & 1738 & $14.9 \%$ & $28.53[17.72,45.93]$ & & & & - \\
\hline Pawar, 2003 & 4 & 25 & 2 & 927 & $10.2 \%$ & $88.10[15.28,507.78]$ & & & & \\
\hline Roeleveld,2011 & 0 & 11 & 3 & 114 & $6.1 \%$ & $1.39[0.07,28.52]$ & & & & \\
\hline Sheng, 2012 & 27 & 105 & 46 & 1583 & $14.8 \%$ & $11.57[6.83,19.59]$ & & & & \\
\hline Tamayo,2012 & 61 & 124 & 30 & 1486 & $14.8 \%$ & $46.99[28.37,77.84]$ & & & & $\rightarrow$ \\
\hline Tang, 2009 & 5 & 13 & 4 & 87 & $11.2 \%$ & $12.97[2.89,58.22]$ & & & & \\
\hline Torres,1990 & 26 & 78 & 47 & 244 & $14.7 \%$ & $2.10[1.19,3.70]$ & & & - & \\
\hline Total (95\% Cl) & & 482 & & 7130 & $100.0 \%$ & $15.18[5.81,39.68]$ & & & & \\
\hline Total events & 178 & & 203 & & & & & & & \\
\hline $\begin{array}{l}\text { Heterogeneity: Tau² } \\
\text { Test for overall effec }\end{array}$ & $\begin{array}{l}1.55 ; \mathrm{Chi} \\
\mathrm{Z}=5.55\end{array}$ & $\begin{array}{l}2=87.0 \\
P<0.0\end{array}$ & $\begin{array}{l}02, \mathrm{df}=7 \\
0001)\end{array}$ & $(P \approx$ & 1001) & $92 \%$ & 0.002 & $\begin{array}{c}0.1 \\
\text { non-VAP }\end{array}$ & VAP & 500 \\
\hline
\end{tabular}

\section{ICU stay time}

\begin{tabular}{|c|c|c|c|c|c|c|c|c|c|c|c|c|}
\hline \multirow[b]{2}{*}{ Stucty or Subgroup } & \multicolumn{3}{|c|}{ VAP } & \multicolumn{3}{|c|}{ non-VAP } & \multirow{2}{*}{\multicolumn{2}{|c|}{$\begin{array}{cc} & \text { Mean Difference } \\
\text { Weight } & \text { N, Random, } 95 \% \mathrm{Cl} \\
\end{array}$}} & \multirow{2}{*}{\multicolumn{4}{|c|}{$\begin{array}{l}\text { Mean Difference } \\
\text { N, Random, } 95 \% \mathrm{Cl}\end{array}$}} \\
\hline & Mean & SD & Total & Mean & SD & Total & & & & & & \\
\hline Pawar, 2003 & 14.32 & 8.98 & 25 & 3.57 & 2.03 & 927 & $20.0 \%$ & $10.75[7.23,14.27]$ & & & - & \\
\hline Roeleveld,2011 & 13 & 6.8 & 11 & 10.4 & 10.2 & 114 & $19.9 \%$ & $2.60[-1.83,7.03]$ & & & & \\
\hline Sheng,2012 & 24.7 & 4.5 & 105 & 3.2 & 1.5 & 1583 & $20.2 \%$ & $21.50[20.64,22.36]$ & & & $=$ & \\
\hline Tamayo,2012 & 29.6 & 29.4 & 124 & 4.2 & 8.1 & 1486 & $19.8 \%$ & $25.40[20.21,30.59]$ & & & $\rightarrow$ & \\
\hline Tang,2009 & 63.15 & 4.715 & 13 & 7.21 & 0.912 & 87 & $20.1 \%$ & $55.94[53.37,58.51]$ & & & & 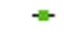 \\
\hline Total (95\% Cl) & & & 278 & & & 4197 & $100.0 \%$ & $23.28[6.65,39.91]$ & & & & \\
\hline $\begin{array}{l}\text { Heterogeneity: Tau } \\
\text { Test for overall effec }\end{array}$ & $\begin{array}{l}356.64 \\
Z=2.74\end{array}$ & $\begin{array}{l}\mathrm{Chi}^{2}= \\
(\mathrm{P}=0 .\end{array}$ & $\begin{array}{l}768.66 \\
006)\end{array}$ & $d f=4$ & $P<0.0$ & $0001) ;$ & $=99 \%$ & & -50 & -25 & 25 & 50 \\
\hline
\end{tabular}

FIGURE E3. Meta-analysis of clinical outcomes. A, Mortality; B, length of stay in the intensive care unit. VAP, Ventilator-associated pneumonia; $M$ - $H$, Mantel-Haenszel; $C I$, confidence interval; $I C U$, intensive care unit; $S D$, standard deviation; $I V$, inverse variance. 

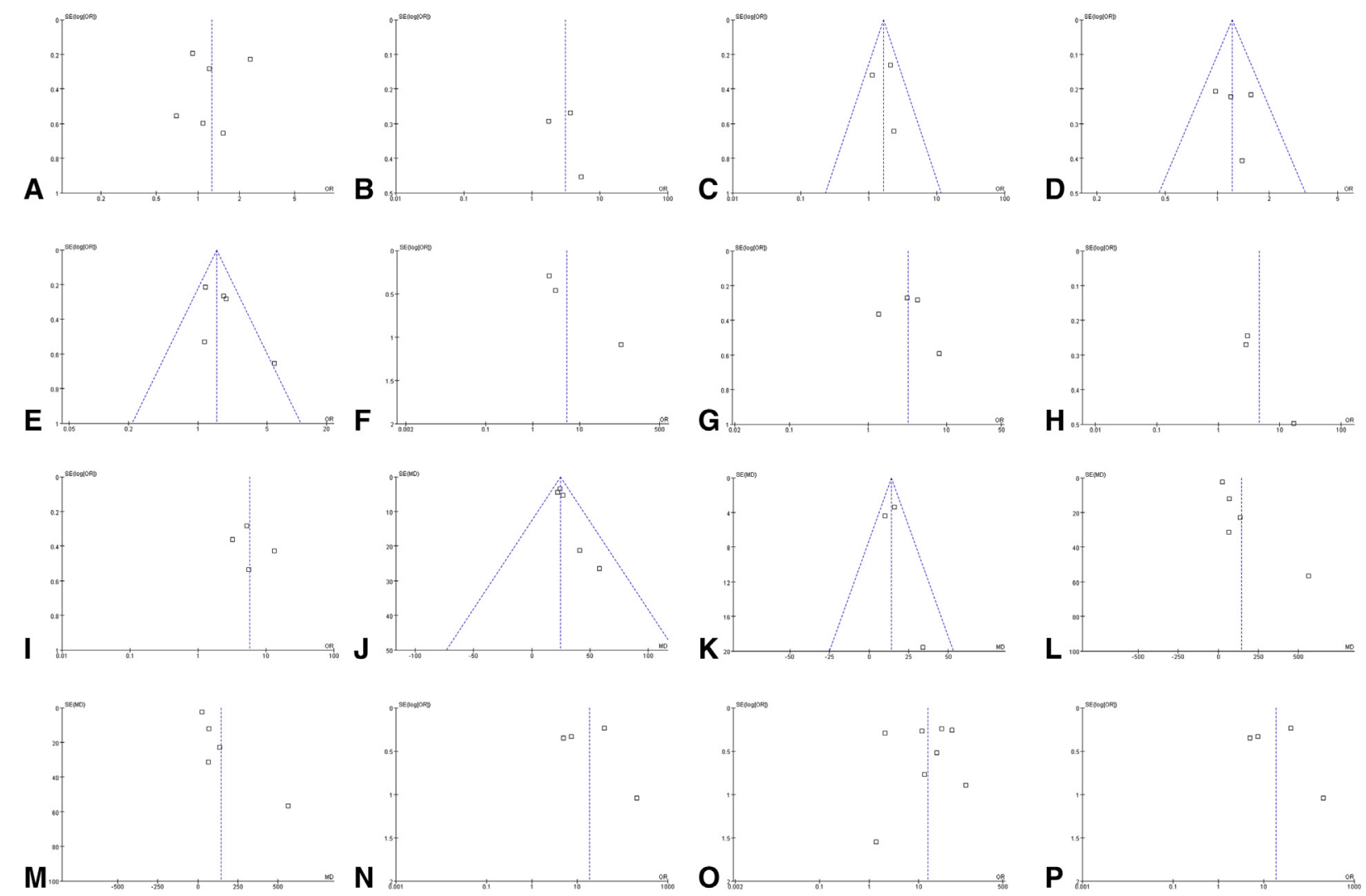

FIGURE E4. Funnel plots of each analysis. A, Gender; B, New York Heart Association cardiac function class IV; C, pulmonary hypertension; D, diabetes mellitus; E, chronic obstructive pulmonary disease; F, peripheral vascular disease; G, renal disease; H, emergency surgery; I, intra-aortic balloon counterpulsation; J, cardiopulmonary bypass time; K, aortic crossclamp time; L, mechanical ventilation time; M, reintervention; N, reintubation; $\mathrm{O}$, mortality; $\mathrm{P}$, length of stay in the intensive care unit. $S E$, Standard error; $O R$, odds ratio; $M D$, mean difference. 
TABLE E1. Quality assessment of the studies using the Newcastle-Ottawa quality scale

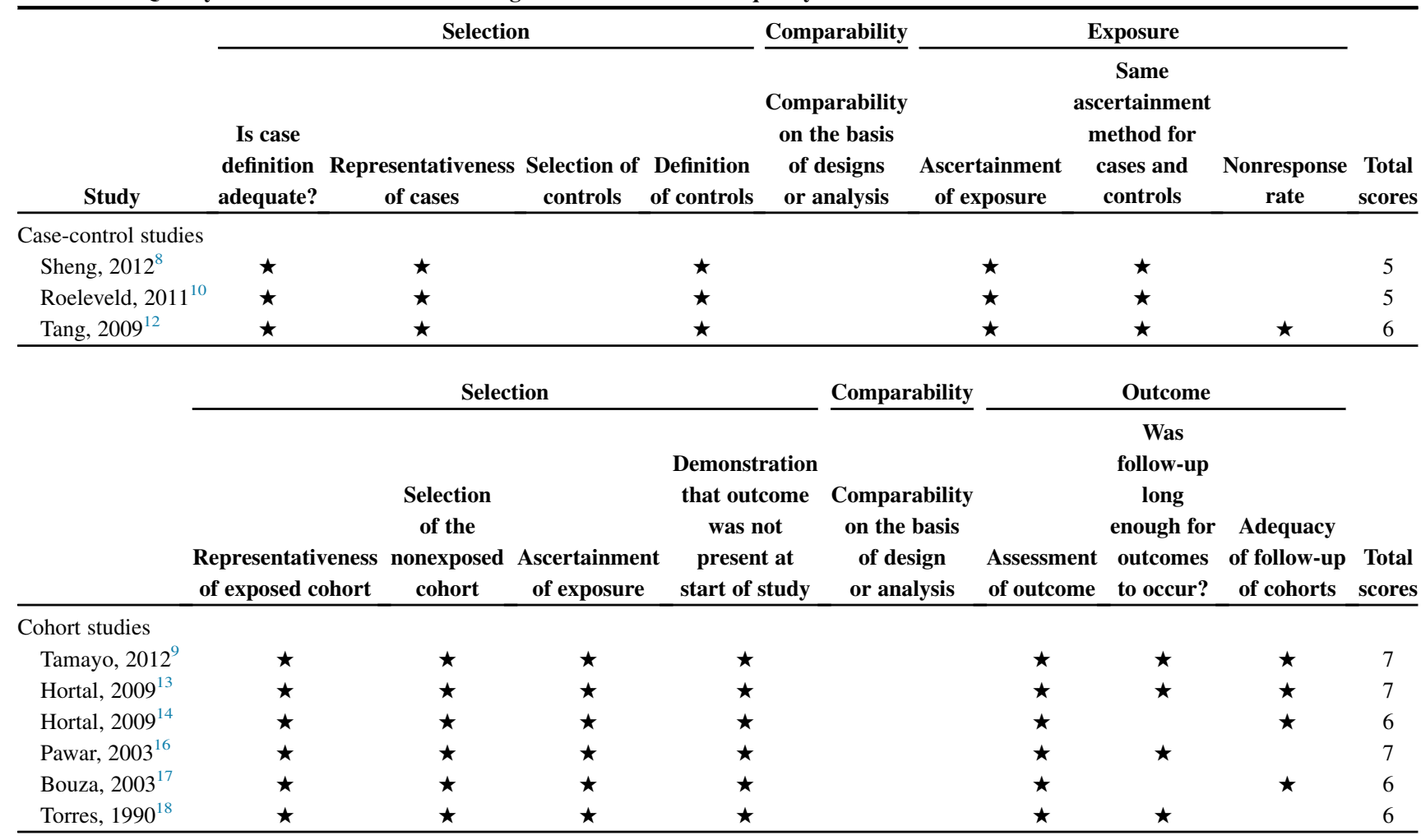

